\title{
The Difference of Effectiveness of Ginger Warm Compress and Consumption of Acidic Turmeric on Decreasing Primary Menstrual Pain Scale
}

\author{
Matilda Bupu Ria, Clara Yunita Ina Ola, Damita Palalangan
}

Diploma III of Midwifery, Schol of Health Ssciences Maranatha, Kupang, East Nusa Tenggara

\section{ABSTRACT}

Background: Dysmenorrhoea is pain during menstruation that is felt by teenage women, usually they experience cramps and are concentrated in the lower abdomen. Complaints of menstrual pain can vary, ranging from mild to severe. The purpose of this study was to analyze the difference in the effectiveness of ginger warm compresses and the consumption of tamarind turmeric on reducing the primary menstrual pain scale.

Subjects and Method: This study was conducted using a quasi-experimental type two group pre post test design, with a population of all female students who experienced primary menstrual pain and a sample of 30 respondents with warm ginger compresses and 30 respondents who consumed tamarind and turmeric drinks. The sample was collected by purposive sampling. The data were collected by questionnaire. The independent variable was warm compresses of ginger and consumption of tamarind turmeric, the dependent variable was primary menstrual pain. The analysis used was the Wilcoxon and Mann Whitney tests.

Results:Based on the results of the Wilcoxon test, there was an effect of giving a warm ginger compress $(\mathrm{p}=$ 0.004). Likewise, giving tamarind turmeric drink showed an effect with the result $\mathrm{p}<0.001$. Based on the results of the Mann Whitney test, there was a significant difference in the effectiveness of ginger warm compresses and the consumption of tamarind turmeric on reducing the primary menstrual pain scale, with $\mathrm{p}=<0.001$ results.

Conclusion: It is hoped that respondents, readers, further researchers, and especially young women who experience menstrual pain, consume tamarind regularly in dealing with primary menstrual pain complaints as a non-pharmacological therapy.

Keywords: primary menstrual pain, warm compresses of ginger, consumption of tamarind turmeric.

\section{Correspondence:}

Matilda Bupu Ria. Diploma III of Midwifery, School of Health Sciences Maranatha. Jl. Kamp. Bajawa Nasipanaf, Kupang, East Nusa Tenggara. E-mail: matildabupuria19@gmail.com. Mobile +6281241254153 .

Cite this as:

Ria MB, Ola CYI, Palalangan D (2021). The Difference of Effectiveness of Ginger Warm Compress and Consumption of Acidic Turmeric on Decreasing Primary Menstrual Pain Scale. J Matern Child Health. 06(03): 285-294. https://doi.org/10.26911/thejmch.2021.06.03.03.

(c) (i) (-) Journal of Maternal and Child Health is licensed under a Creative Commons Journal of Maternal and Child Health is licensed under a Creative Con
Attribution-NonCommercial-ShareAlike 4.o International License.

\section{BACKGROUND}

Dysmenorrhoea is defined as pain during menstruation, usually cramping and concentrated in the lower abdomen. Complaints of menstrual pain can vary from mild to severe. Dysmenorrhoea is divided into 2, namely primary dysmenorrhoea and secondary dysmenorrhoea. Primary dysmenorr- hoea is caused by no gynecological proble$\mathrm{ms}$ that occur after menarche until the age of 25 years and secondary dysmenorrhoea is caused by gynecological disorders experienced by people over 25 years of age. The age of 15-25 years is the age where primary dysmenorrhoea will reach its maximum 
and as a consequence the patient must leave his job for hours to rest (Andira, 2013).

According to the World Health Organization, the incidence of menstrual pain in the world is very high. The incidence of dysmenorrhoea was $1,769,425$ people (90\%) with 10-15\% experiencing severe dysmenorrhoea. On average, more than 50\% of women in every country experience menstrual pain. The incidence of menstrual pain in adolescents is reported to be around 92\%, from Sweden reported menstrual pain in $90 \%$ of women aged less than 19 years and $67 \%$ of women aged 24 years (Proverawati et al., 2012).

The prevalence of dysmenorrhoea in the United States is estimated at $45-90 \%$ (Anurogo et al., 2011). In Mexico the incidence of dysmenorrhoea reaches $64 \%$, Italy 68\%, Jordan 55.8\%, Turkey $84.9 \%$, and Malaysia 74.5\% (Ortiz, 2010; Ping et al., 2010; Al-jefout et al., 2014; Seven et al., 2014; Zannoni et al., 2014).

The incidence of dysmenorrhoea in Indonesia is also no less high compared to other countries in the world, the incidence of dysmenorrhoea in Indonesia consists of $54.89 \%$ primary dysmenorrhoea and $\mathbf{2 1 . 1 1} \%$ secondary dysmenorrhoea with dysmenorrhoea incidence around 9.36\% among women of productive age (Astari et al., 2020).

In East Nusa Tenggara (NTT), the number of reproductive girls aged 10-24 years is 56,598 . Meanwhile, those who experienced menstrual pain and came to the midwife were 11,565 people (1.31\%) (BPS Provinsi NTT, 2018).

Based on a preliminary study on May 15, 2019 at the D-III Obstetrics Study Program, Maranatha Kupang, East Nusa Tenggara, data was obtained that out of 100 menstruating respondents, 70 experienced dysmenorrhea and did not use pharmacological or non-pharmacological therapies and they did not experience more than two dysmenorrhea. day but quite disturbing routine activities carried out. This shows that there are still many young women who experience dysmenorrhoea, which interferes with their activities.

Primary dysmenorrhoea can be handled pharmacologically and non pharmacologically. Pharmacological treatment of primary dysmenorrhea can be done with drugs that can relieve menstrual pain (analgesics), while treatment of primary dysmenorrhoea can be done nonpharmacologically, namely herbal concoction therapy that has been believed to have its properties derived from traditional plant ingredients. Some plants that are believed to reduce menstrual pain are turmeric, tamarind, cinnamon, cloves and ginger (Anurogo, 2011).

Herbal plants that can be used to relieve primary menstrual pain are ginger and tamarind. Ginger in traditional medicinal ingredients functions as a stimulant drug for large mucous membranes (stimulants), digestion and flatulence (carminativa), rheumatism, headaches, and antihardening of the arteries. Ginger compress contains cyclo oxygenation enzymes that can reduce pain in primary dysmenorrhoea. In addition, ginger also has a burning effect which can relieve pain, stiffness and muscle spasm or the occurrence or vasodilation of blood vessels (Susanti, 2014).

In addition to ginger, herbal ingredients that can be used to reduce menstrual pain are tamarind turmeric drink, the content of curcumine in turmeric and anthocyanins in acids will inhibit the cyclooxygenase (COX) reaction so that it inhibits or reduces the occurrence of inflammation so that it will reduce or even inhibit uterine contractions that cause menstrual pain (Leli, 2011). 
Ria et al./ Effectiveness of Ginger Warm Compress and Consumption of Acidic Turmeric

Based on the description above, the researcher was interested in conducting a study to analyze the difference in the effectiveness of ginger warm compresses and consumption of tamarind turmeric.

\section{SUBJECTS AND METHOD}

\section{Study Design}

This research is a quasi experimental research with the type of two groups pre post test design.

\section{Population and Sample}

The research was conducted on students of the D-III Midwifery Study Program at STIKes Maranatha Kupang, East Nusa Tenggara in 2019 who experienced primary menstrual pain. The data in this study were taken from June to July 2019. A total of 60 female students was selected by purposive sampling. The sample consisted of 30 female students being treated in the form of a warm ginger compress which was given once in 20 minutes, while 30 other female students were given treatment in the form of consuming tamarind turmeric on the first and second day of menstruation.

\section{Study Variables}

The independent variables in this study were warm compresses of ginger and consumption of tamarind turmeric. Meanwhile, the dependent variable was primary menstrual pain.

\section{Operational Definition of Variables}

Menstrual pain scale before giving warm compress ginger was defined as the pain scale during menstruation before being given a warm compress ginger on the top of the symphysis pubis once for 20 minutes.

Menstrual pain scale after giving warm compress ginger was defined as the pain scale during menstruation after being given a warm compress ginger on the top of the symphysis pubis once for 20 minutes.

Menstrual pain scale before consuming turmenic acid was defined as the pain scale during mensturation before being consumed $200 \mathrm{ml}$ turmenic acid liquid on the first and second day of menstruation.

Menstrual pain scale after consuming turmenic acid was defined as the pain scale during mensturation before being consumed $200 \mathrm{ml}$ turmenic acid liquid on the first and second day of menstruation.

\section{Study Instruments}

Data were collected through interviews using a questionnaire and giving treatment to the research subjects.

\section{Data Analysis}

Data were analyzed univariately using frequency distribution tables and biavariate using the Wilcoxon signed rank test and Mann Whitney statistical tests with the help of the SPSS 22 application.

The Wilcoxon test was conducted to analyze differences in primary menstrual pain in students before and after being given warm ginger compresses and to analyze differences in primary menstrual pain in students before and after being given tamarind turmeric consumption. Meanwhile, the Mann Whitney test was conducted to analyze differences in primary menstrual pain in students with warm ginger compresses and consumption of tamarind turmeric.

\section{RESULTS}

\section{Sample Characteristics}

Table 1 shows the characteristics of the sample in this study including age, age of menarche, duration of dysmenorrhoea, time of menstrual pain that is felt, and therapy performed during menstrual pain.

Based on table 1, it can be seen that students who are given warm ginger compresses are mostly aged 19-20 years, namely as many as 14 people (46.7\%), while almost half of the female students who are given tamarind drink consumption are 19- 
Ria et al./ Effectiveness of Ginger Warm Compress and Consumption of Acidic Turmeric

20 years old, namely as many as 13 people (43.3\%).

Half of the students who were given warm ginger compresses experienced menarche at the age $<12$ years, as many as 15 people (50.0\%), while the students who were given tamarind turmeric consumption mostly experienced menarche at the age $<12$ years, as many as 16 people (53.3\%).

In Table 1, it shows that almost half of the female students who were given warm compresses of ginger and those who were given consumption of tamarind turmeric experienced dysmenorrhea for $>2$ days as many as 12 people (40.0\%). Almost half of the students who were given ginger warm compresses experienced dysmenorrhea on the first day of menstruation as many as 13 people $(43.4 \%)$, while the students who were given tamarind consumption experienced dysmenorrhea on the first day of menstruation, namely 16 people (53.4\%). Students who were given warm compresses of ginger and those who were given consumption of tamarind turmeric all did not do any therapy during dysmenorrhea (100\%).

Table 1. Characteristics of study subjects

\begin{tabular}{|c|c|c|c|c|c|}
\hline \multirow{2}{*}{ Characteristics } & \multirow{2}{*}{ Category } & \multicolumn{2}{|c|}{$\begin{array}{c}\text { Ginger warm } \\
\text { compress }\end{array}$} & \multicolumn{2}{|c|}{$\begin{array}{c}\text { Consuming tamarind } \\
\text { and turmeric }\end{array}$} \\
\hline & & $\mathbf{N}$ & $\%$ & $\mathbf{N}$ & $\%$ \\
\hline \multirow[t]{3}{*}{ Age } & 19-20 years & 14 & 46.7 & 13 & 43.3 \\
\hline & 21-22 years & 11 & 36.7 & 11 & 36.7 \\
\hline & 23-25 years & 5 & 16.6 & 6 & 20.0 \\
\hline \multirow{3}{*}{ Menarche Age } & $<12$ years & 15 & 50.0 & 16 & $53 \cdot 3$ \\
\hline & $12-16$ years & 11 & 36.7 & 12 & 40.0 \\
\hline & 16 years & 4 & $13 \cdot 3$ & 2 & 6.7 \\
\hline \multirow{3}{*}{$\begin{array}{l}\text { Duration of } \\
\text { dismenorhea }\end{array}$} & 1 day & 8 & 26.7 & 7 & 23.3 \\
\hline & 2 day & 10 & 33.3 & 11 & 36.7 \\
\hline & $>2$ day & 12 & 40.0 & 12 & 40.0 \\
\hline \multirow{3}{*}{$\begin{array}{l}\text { Time of } \\
\text { menstrual pain }\end{array}$} & Before Menstruation & 10 & 33.3 & 7 & $23 \cdot 3$ \\
\hline & First Day of Menstruation & 13 & 43.4 & 16 & 53.4 \\
\hline & During menstruation & 7 & 23.3 & 7 & 23.3 \\
\hline \multirow{3}{*}{$\begin{array}{l}\text { Therapy } \\
\text { performed }\end{array}$} & Nothing & 30 & 100 & 30.0 & 100 \\
\hline & Pharmacology & 0 & 0.0 & 0 & 0.0 \\
\hline & Non Pharmacology & 0 & 0.0 & 0 & 0.0 \\
\hline
\end{tabular}

Table 2 shows that before being given a warm ginger compress, the median value of menstrual pain was 4.00. Meanwhile, after being given a warm ginger compress, the median value of menstrual pain was 4.0o, with a menstrual pain range between 2.00 and 7.00.

Table 3 shows that before being given tamarind turmeric consumption, the median of menstrual pain was 5.00. Meanwhile, after being given tamarind consumption, the median value of menstrual pain was 3.00 , with a menstrual pain range from 1.00 to 6.00 .

\section{Bivariate Analysis}

In Table 4 shows that there is a significant difference in the effectiveness of reducing menstrual pain before and after ginger warm compresses $(\mathrm{p}=0.004)$.

Table 5 showed that there is a significant difference in the effectiveness of reducing menstrual pain before and after consuming tamarind turmeric $(\mathrm{p}<0.001)$.

Table 6 shows that $\mathrm{p}<0.001$, therefore, there is a significant difference in the effectiveness of giving warm compresses of ginger and consumption of turmeric to decrease the primary menstrual pain scale. 
Ria et al./ Effectiveness of Ginger Warm Compress and Consumption of Acidic Turmeric

Table 2 Distribution of Menstrual Pain Scale Before and After Ginger Warm Compress

\begin{tabular}{|c|c|c|c|c|}
\hline Variable & $\mathbf{n}$ & Median & Min. & Max. \\
\hline $\begin{array}{l}\text { Menstrual Pain Level Before Giving Ginger Warm } \\
\text { Compress }\end{array}$ & 30 & 4.00 & 2.00 & 7.00 \\
\hline $\begin{array}{l}\text { Menstrual Pain Level After Giving Ginger Warm } \\
\text { Compress }\end{array}$ & 30 & 4.00 & 2.00 & 7.00 \\
\hline
\end{tabular}

Table 3 Distribution of Primary Menstrual Pain Scale Before and After the Consumption of Tamarind Turmeric

\begin{tabular}{lcccc}
\hline \multicolumn{1}{c}{ Variable } & N & Median & Min. & Max. \\
\hline $\begin{array}{l}\text { Menstrual Pain Level Before Giving tamarind } \\
\text { turmeric }\end{array}$ & 30 & 5.00 & 3.00 & 7.00 \\
$\begin{array}{l}\text { Menstrual Pain Level After Giving tamarind } \\
\text { turmeric }\end{array}$ & 30 & 3.00 & 1.00 & 6.00 \\
\hline
\end{tabular}

Table 4 Wilcoxon Test Results on Differences in Effectiveness of Primary Menstrual Pain Scale Decrease in Students Before and After Ginger Warm Compress

\begin{tabular}{llllcccc}
\hline \multicolumn{2}{c}{ Variable } & N & Median & Min. & Max. & p \\
\hline $\begin{array}{l}\text { Menstrual Pain Level Before Giving Ginger } \\
\text { Warm Compress }\end{array}$ & 30 & 4.00 & 2.00 & 7.00 & \\
$\begin{array}{l}\text { Menstrual Pain Level After Giving Ginger } \\
\text { Warm Compress }\end{array}$ & & 30 & 4.00 & 2.00 & 7.00 & 0.004 \\
\hline
\end{tabular}

Table 5: Wilcoxon Test Results on Differences in the Effectiveness of the Decrease in Primary Menstrual Pain Scale in Students Before and After Consuming Acid Turmeric

\begin{tabular}{lccccc}
\hline \multicolumn{1}{c}{ Variable } & N & Median & Min. & Max. & p \\
\hline $\begin{array}{l}\text { Level of Menstrual Pain Before Given Turmeric } \\
\text { Acid }\end{array}$ & 30 & 5.00 & 3 & 7 & \\
$\begin{array}{l}\text { Level of Menstrual Pain After Given Turmeric } \\
\text { Acid }\end{array}$ & 30 & 3.00 & 1 & 6 & $<0.001$ \\
\hline
\end{tabular}

Table 6 Mann Whitney Test Results on Differences in the Effectiveness of Ginger Warm Compress and Consumption of Acid Turmeric on Decreasing Primary Menstrual Pain Scale

\begin{tabular}{lcccc}
\hline \multicolumn{1}{c}{ Variable } & Median & Min. & Max. & p \\
\hline Ginger warm compress post-pre intervention & 0.00 & 0 & 2 & $<0.001$ \\
Post-pre intervention for sour turmeric consumption & 1.00 & 0 & 2 & \\
\hline
\end{tabular}

\section{DISCUSSION}

1. Menstrual Pain Scale Before Giving Warm Compress Ginger

Based on table 2, it shows that the menstrual pain scale of respondents before being given warm ginger compresses was at most on a scale of 4 , with a scale ranging from a scale of 2 to a scale of 7 . This menstrual pain scale was included in the category of moderate menstrual pain.

Primary dysmenorrhoea is menstrual pain that is found without any obvious abnormalities in the genital organs. Primary dysmenorrhoea occurs some time after menarche usually after 12 months or more, because menstrual cycles in the first month after menarche are generally anovulatory type that is not accompanied 
by pain. The pain occurs shortly before or with the onset of menstruation and lasts for several hours, although in some cases it may last several days. The pain experienced is like multiple seizures, usually limited to the lower abdomen, but can spread to the waist and thighs (Hermawan, 2012).

Based on table 1, it shows that half of the respondents experienced menarche at the age $<12$ years. So it is possible for respondents to experience menstrual pain on a moderate scale, because earlier menarche at $<12$ years of age is one of the factors that influence the scale of menstrual pain. This is in line with Bare et al. (2002) which states that women who experience menarche at the age of $<12$ years cause the reproductive organs to not function optimally and are not ready to experience changes so that menstrual pain occurs. In addition, almost half of the respondents aged 19-20 years, namely 14 people ( $46.7 \%)$, this shows that the respondents are still young so that menstrual pain is heavier, this is in accordance with the opinion of Bare et al. (2002) which states that the younger a person is, the more likely he is to experience pain every time he menstruates.

Based on the researchers' observations, respondents reacted to menstrual pain in different ways. Respondents showed a variety of typical behavior or body movements and grinning facial expressions but were still able to pinpoint the location of the pain and were able to discuss the pain experienced and were able to follow the researchers' instructions well. In addition, the disruption of physical activity that occurs in the respondent causes the respondent to concentrate less in studying because of menstrual pain they experience.

2. Menstrual Pain Scale After Giving Warm Ginger Compress

Table 2 shows that the menstrual pain scale of respondents before being given warm ginger compresses was at most on a scale of 4 , with a scale ranging from a scale of 2 to a scale of 7. This menstrual pain scale was included in the category of moderate menstrual pain.

Ginger compress according to Mintarsih et al. (2014) can reduce pain in primary dysmenorrhea. Ginger compress is a traditional treatment to reduce primary dysminorrhea pain. Ginger compress contains cyclo oxygenation enzymes that can reduce pain in primary dysminorrhea. In addition, ginger (Zingiber Officinale Rosc) contains oleoresin which can provide a warm effect that can relieve pain (Setiawan, 2015).

Ginger also has the effect of hot and spicy taste, where this hot feeling can relieve pain, stiffness and muscle spasm or the occurrence of vasodilation of blood vessels, the maximum benefit will be achieved within 20 minutes after heat application. The decrease in the intensity of menstrual pain experienced by respondents in the experimental group was due to the impulses that suppress the pain so that the pain was reduced. These impulses are in the form of warmth which is the effect of a ginger compress that hits the painful part of the lower abdomen. The local response to heat occurs through stimulation of nerve endings, which are deep in the skin and sensitive to temperature. This stimulation sends impulses from the periphery to the hypothalamus which will cause awareness of the local temperature and trigger an adaptive response to maintain normal body temperature.

\section{Menstrual Pain Scale Before Given Consumption of Turmeric Acid}

Based on table 3, it shows that the menstrual pain scale of respondents before being given tamarind consumption is at most on a scale of 5 , with a scale ranging from 3 to 7 . This menstrual pain scale is 
included in the category of moderate menstrual pain.

Dysmenorrhoea causes pain in the lower abdomen, which can radiate to the lower back and legs. Pain is felt as a cramp that comes on and off or as a dull ache that is persistent. Usually the pain starts just before or during menstruation, reaches a peak within 24 hours and after 2 days will disappear. Dysmenorrhoea is also often accompanied by headaches, nausea, constipation, or diarrhea and frequent urination. Sometimes vomiting occurs (Suparyanto, 2011).

The age of the respondents who are still young affects the level of the pain scale they experience because at a younger age the cervix is still narrow. This is in line with Bare et al. (2002) which states that women who are older will have more frequent menstruation, the cervix will widen, so that in old age the incidence of dysmenorrhoea is rare.

In addition, some respondents experienced menarche at $<12$ years of age, earlier menarche at $<12$ years of age was one of the factors that influenced the scale of menstrual pain. This is in line with Bare et al. (2002) which states that women who experience menarche at the age of $<12$ years cause the reproductive organs to not function optimally and are not ready to experience changes so that menstrual pain occurs. As for other factors that can affect the occurrence of menstrual pain apart from age and age of menarche, these factors are the duration of menstruation that is more than normal, nutritional status, and never being pregnant or giving birth (Bare et al., 2002).

All respondents did not take any action, either pharmacological or non-pharmacological, to reduce menstrual pain because they understood that menstrual pain was a physiological condition that would heal itself, although many respondents recognized that menstrual pain was quite disruptive to daily activities.

\section{Menstrual Pain Scale After Given Consumption of Turmeric Acid}

Since a long time ago, tamarind turmeric was used to reduce menstrual pain during menstruation (Purwanto et al., 2013). Turmeric has long been used as an anti-bacterial, anti-inflammatory, and anti-oxidant (Mary et al., 2012). According to data from the Traditional Medicine Industry (IOT) and IKOT (Small Traditional Medicine Industry), from $4,187,40 \%$ of the people use turmeric as a treatment and $10 \%$ of people consume turmeric to reduce menstrual pain (Ningharmanto et al., 2011).

Tamarind fruit has many trusted medical benefits, especially the content of xylose, xyloglycans, and anthocyanins found in these fruits. Xylose and xyloglycans are very useful in terms of anti-inflammatory and anti-pyretic and anthyocyanin because these agents can inhibit the action of the cycloaxygenase (COX) enzyme so that it can inhibit the release of prostaglandins so as to reduce pain. While the ingredients of tannins, saponins, sesquiterpenes, alkaloids, and phlobatamins will be very useful for reducing nervous system activity (Hatcher et al., 2011). The content of flavonoids contained in acids also functions as pain relievers and sweating (Sina, 2012).

\section{Analysis of the effectiveness of menstrual pain scale decrease before and after ginger warm compress}

Based on table 4 , it shows that there is a significant difference in the effectiveness of reducing menstrual pain before and after being given warm ginger compresses.

This study is in line with Maidarti et al. (2018) who showed that giving ginger warm compresses had an effect on the effectiveness of reducing the primary 
menstrual pain scale, from the results of the study by Maidarti et al. (2018) the decrease in the average pain scale was only reduced by 1 stage, such as from moderate pain to mild pain, or severe pain to moderate pain.

The reduction in menstrual pain after being given a warm ginger compress on the lower abdomen of the respondent for 20 minutes was due to the widening of the blood vessels, causing impulse stimulation that blocks the perception of pain from reaching the hypothalamus. Apart from that, the hot and spicy effect of ginger also helps relieve pain, stiffness and spasm of the lower abdominal muscles that cause menstrual pain.

Of the 30 respondents, there was a decrease in the median value from a scale of 5 before being given tamarind turmeric to a scale of 3 after being given tamarind turmeric. This may occur because the treatment is only done once and then the pain scale is repeated again. Of course, the effect of reducing the menstrual pain scale will be more visible if the menstrual pain compress is done not only once a day.

\section{Analysis of the Effectiveness of the Decrease in Menstrual Pain Scale Before and After the Consumption of Tamarind Turmeric}

The results of statistical tests using the Wilcoxon signed rank test showed that there was a significant difference in the effectiveness of reducing menstrual pain before and after consuming tamarind turmeric. The results of this study are in line with the research of Sugiharti et al. , (2018) which showed that there was a significant difference in decreasing the primary menstrual pain scale before and after being given tamarind turmeric ( $\mathrm{p}<0.001)$.

Marsaid et al. (2018) also showed the same results, namely before being given tamarind turmeric extract most of the respondents experienced moderate mens- trual pain. Meanwhile, after being given tamarind turmeric extract most of the respondents did not experience menstrual pain. Therefore, it is recommended that young women consume tamarind turmeric regularly to reduce the symptoms of menstrual pain they feel.

\section{Analysis of the effectiveness of givi-}

ng ginger warm compress and consumption of acidic turmeric on decreasing menstrual pain scale

In this study, it was found that giving ginger warm compresses and consuming tamarind turmeric were equally effective in reducing the scale of menstrual pain. This is because ginger and tamarind contain active substances that can reduce pain scale which has a function as anti-inflammatory, analgesic, and anti-oxidant. This is in line with the research of Sugiharti et al. (2018) which states that the content of ginger and tamarind is effective in decreasing the menstrual pain scale.

The results of the post-pre warm ginger compress statistical test and postpre consumption of tamarind turmeric showed that there was a significant difference in the effectiveness of ginger warm compresses and tamarind consumption on reducing menstrual pain. This can occur because giving warm compresses of ginger and consumption of tamarind turmeric both have good effectiveness in reducing the scale of menstrual pain.

However, if it is seen from its effectiveness by looking at the distribution of the two data, there is a difference in the median value of the menstrual pain scale, when giving tamarind compresses has a median value of 1 with a value range of $o$ to 2. Meanwhile, ginger warm compresses have a median value of $o$ with The value ranges from $o$ to 2 . So, it can be concluded that the consumption of tamarind turmeric is more effective in reducing the menstrual 
Ria et al./ Effectiveness of Ginger Warm Compress and Consumption of Acidic Turmeric

pain scale when compared to giving ginger warm compresses.

From these various analyzes, it can be concluded that there is a significant difference in the effectiveness of warm compresses of ginger and consumption of tamarind turmeric on reducing the primary menstrual pain scale. Giving tamarind turmeric is more effective than giving ginger warm compresses. So it is hoped that respondents, readers, further researchers, and especially young women who experience menstrual pain, consume tamarind regularly in dealing with complaints of primary menstrual pain as a non-pharmacological therapy.

\section{AUTHOR CONTRIBUTION}

Data items extracted from research articles include title, author, publication journal, publication year, location and time of study, type of study, research variables, measurement methods, population characteristics, inclusion and exclusion criteria, statistical methods, data analysis and discussion. Data extraction was carried out independently by 3 authors (MBR, CYIO, and DP). All authors review final summaries of selected studies and complete all incompatible data through discussion.

\section{CONFLICT OF INTEREST}

There is no conflict of interest in this study.

FUNDING AND SPONSORSHIP

This study is self-funded.

ACKNOWLEDGEMENT

We would like to thank the students of the D-III Midwifery Study Program at STIKes

\section{REFERENCE}

Atik D, Cander B, Dikmetaş C, Bulut B, Sert

E, Kaya H, Güven R, et al. (2020). Trafik Kazası ile Gelen Pediatrik
Hastalarda, Kaza Oluş Şekilleri ile Travma Skorlarının Değerlendirilmesi, Uludağ Üniversitesi Tip Fakültesi Derg, 46(1):47-52. doi: 10.32708/uutfd.655843.

Andira D (2013). Seluk beluk kesehatan reproduksi wanita (The ins and outs of female reproductive health). Yogyakarta: A Plus Book.

Anurogo, Wulandari (2014). Cara mengatasi nyeri haid (How to deal with menstrual pain). Yogyakarta: Andi offset.

Astari RY, Audina C (2020). Effect of warm compress, ginger drink and turmeric drink on the decrease of menstrual pain. Junal kebidanan, 10(1): 67-73.

Ekawati H (2017). Perbedaan efektifitas pemberian minuman jahe dan kunyit asam terhadap penurunan dismenorhea pada mahasiswa semester VII Keperawatan Stikes Muhamadiyah Lamongan Tahun 2017 (Differences in the effectiveness of giving ginger and tamarind turmeric to decrease dysmenorrhea in seventh semester students of Nursing at Stikes Muhamadiyah Lamongan in 2017). Jurnal Surya, 09(01).

Hana, Mutiara (2017). Pengaruh jahe terhadap nyeri saat menstruasi (The effect of ginger on menstrual pain). Journal majority, 06(01).

Hermawan (2012). Dismenorea (nyeri saat haid). Available at: http://ayupermatasarihermawan.blogspot.com

[Accessed Agustus 2018].

Kostania G, Kurniawati A (2016). Perbedaan efektivitas ekstrak jahe dengan ekstrak kunyit dalam mengurangi dismenorhea primer pada mahasiswi di asrama jurusan kebidanan poltekes surakarta (The difference between the effectiveness of ginger extract and turmeric extract in reducing primary 
Ria et al./ Effectiveness of Ginger Warm Compress and Consumption of Acidic Turmeric

dysmenorrhea in female students in the midwifery boarding school at the Surakarta Police Department). Jurnal Terpadu Ilmu Kesehatan, 5(2): 110237.

Leli, Rahmawati, Atik (2011). Pengaruh kunyit asam terhadap penanganan nyeri haid pada siswi kelas XI SMA Negeri Sugihwaras (The effect of tamarind turmeric on the management of menstrual pain in grade XI SMA Negeri Sugihwaras). Jurnal Akses Rajekwesi, 4(2).

Madriati, et al. (2018). Efektivitas terapi etkompres hangat terhadap penurunan nyeri disminorea pada remaja di Bandung (The effectiveness of warm compress therapy on reducing dysmenorrhea pain in adolescents in Bandung). Jurnal Keprawatan BSI, 6(2). http://ejournal.bsi.ac.id/ejurnal/index.php/jk

Mintarsih S, Sugihartiningsih (2018). Kompres jahe berkhasiat untuk menurunkan nyeri haid primer (Ginger compress is effective for reducing primary menstrual pain). STIKES PKU Muhammadiyah Surakarta.

Pattiwaellapia M, et al (2018). Statistik kesehatan Provinsi Nusa Tenggara Timur 2018 (East Nusa Tenggara Province health statistics 2018). Badan Pusat Statistik Provinsi Nusa Tenggara Timur. ISSN: $2517-8541$

Proverawati A, Misaroh (2009). Menarche menstruasi pertama penuh makana
(First menstrual menarche is full of meaning). Yogyakarta: Nuha Medika.

Setiawan (2015). Ginger cultivation. Yogyakarta: Pustaka Baru Press.

Sugiharti RK, Sundari RI (2018). The effectiveness of drinking tamarind turmeric and tamarind ginger on reducing the primary menstrual pain scale. MEDISAINS: Jurnal Ilmiah Ilmu-ilmu Kesehatan, 16(2): 55.

Sukarni I, Wahyu P (2013). Buku Ajar Keprawatan Maternitas (Textbook of Nursing Maternity). Yogyakarta: Nuha Medika.

Mintarsih et al. (2014). Pengaruh kompres jahe terhadap penurunan skala nyeri dismenore di SMA PGRI Bengkulu (Effect of ginger compress on the reduction of dysmenorrhea pain scale in SMA PGRI Bengkulu). Proceeding of The 7th University Research Colloquium 2018: Bidang MIPA dan Kesehatan. [Online] Available at: http://jurnal.ac.id/wpcontent/uploads/2014 /o9/pdf-devi.pdf [Accessed Agustus 2019].

Wulandariet al (2018). Gambaran kejadian dan manajemen dismenorea pada remaja putri di Kecamatan Lima Puluh Kota Pekanbaru (Description of the incidence and management of dysmenorrhoea in young women in Lima Puluh District, Pekanbaru City). JOM FKp. 5(2). 